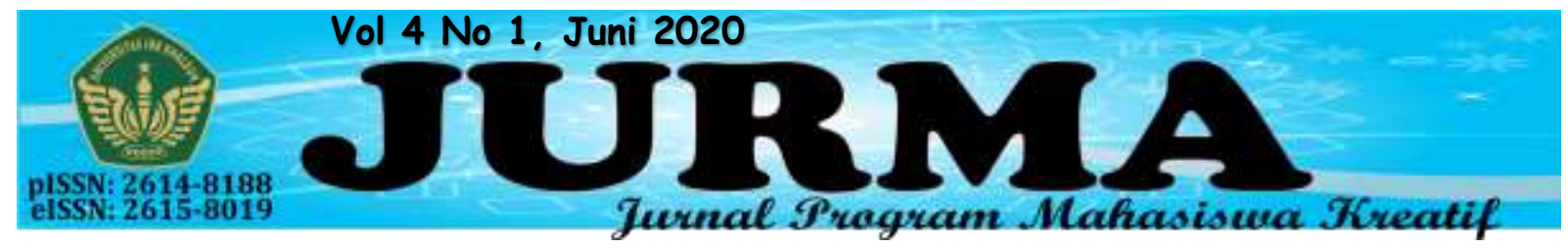

\title{
PROTEKSI DIRI SAAT PANDEMI COVID-19 DI LINGKUNGAN PERUSAHAAN
}

\author{
Supanto $^{1}$ dan Yogi Sirodz Gaos ${ }^{2}$ \\ supanto1994@gmail.com ${ }^{1}$ \\ yogi@uika-bogor.ac.id ${ }^{2}$ \\ Fakultas Teknik dan Sains Universitas Ibn Khaldun, Bogor. ${ }^{1,2}$
}

\begin{abstract}
ABSTRAK
Virus corona Covid-19 dapat menyebar dan menular melalui percikan pada saat batuk dan bersin. Kondisi pasen tertular Covid-19 dapat menujukkan adanya gejala dan tanpa gejala. Masa inkubasi terjadi dalam kurun waktu 7 sampai 14 hari. Keberadaan virus corona memberikan banyak perubahan pada tatanan kehidupan masyarakat dunia. Adanya pandemi ini tentunya akan menjadikan banyak negara berada dalam situasi krisis hebat. Untuk mengatasi hal tersebut keputusan pemerintah tentang akan dilakukannya kenormalan baru atau yang disebut dengan new normal sangat tepat. Secara global WHO juga telah memberikan skenario dalam pelaksanaan kenormalan baru di tengah pandemi. Metode penelitian dilakukan dengan cara memasang poster di lingkungan perusahaan, setiap komputer diberikan screen server tentang bahaya penularan virus corona dan himbauan peraturan protokol kesehatan lewat speaker setiap menjelang isrihatat pertama dan kedua. Dengan tujuan setiap individu dapat memahami dan mematuhi protokol kesehatan sesuai peraturan perusahan demi mencegah penularan Covid-19. Dengan adanya fasilitas yang sudah di berikan seperti hand-sanitizer, masker, vitamin dan melaksankan protokol kesehatan secara ketat terhadap 1025 karyawan, 100 persen sehat dari bulan Maret sampai dengan pertengahan September. Karyawan dapat bekerja dengan nyaman dan produksi dapat berjalan dengan lancar. Dengan kesadaran pentingnya proteksi diri ditengah pandemi covid-19.
\end{abstract}

\section{Kata kunci : Covid-19, cuci tangan, jaga jarak, masker.}

\begin{abstract}
The coronavirus is spread out among people through droplets when coughing and sneezing. Covid19 patient can be identified with symptoms and without symptoms. The incubation period occurs from 7 to 14 days. The existence of the corona virus changes to the life order of the world community. The existence of this pandemic will certainly put many countries in a situation of great crisis. To overcome this, the government's decision about the implementation of the new normal is very appropriate. Globally, WHO has also provided scenarios for the implementation of new norms in the midst of a pandemic. The research method was carried out by putting up posters in the company environment, each computer was given a screen server about the dangers of corona virus transmission and an appeal for health protocol regulations through speakers every time before the first and second concerns. With the aim of each individual being able to understand and comply with health protocols according to company regulations in order to prevent transmission of Covid-19. With the facilities that have been provided such as hand-sanitizers, masks, vitamins and
\end{abstract}


implementing strict health protocols for 1025 employees, 100 percent healthy from March to midSeptember. Employees can work comfortably and production can run smoothly. With the awareness of the importance of self-protection amid the Covid-19 pandemic.

Keywords : Covid-19, wash your hands, keep your distance, masks.

\section{PENDAHULUAN}

Pandemi Covid-19 adalah peristiwa yang menyebabkan penyebaran penyakit di seluruh dunia. penyakit yang disebabkan oleh corona virus jenis baru yang di beri nama SARS-CoV-2. Pertama kalinya wabah Covid-19 terdeteksi di Wuhan, Provinsi Hubei, Tiongkok pada bulan Desember tahun 2019, dan di tetapkan oleh WHO (Organisasi Kesehatan Dunia) pada Maret 2020 hingga April 2020, dari 210 negara telah dilaporkan lebih dari 2 juta kasus Covid-19. wilyah yang mengakibatkan 195,755 orang meninggal dunia dan yang sembuh 781,109 orang (Nakoe et al.).

Tentunya dengan kasus yang sangat besar dan terus bertambah setiap harinya. Pemerintah Indonesia harus mengeluarkan berbagai kebijakan preventif dalam rangka menekan pergerakan kasus Covid-19. Salah satunya dengan di terbitkan darurat Covid-19 ditetepkan berdasarkan dengan Keputusan Presiden (Keppres) Nomor 11 tahun 2020 Tentang Penerapan Kedaruratan Kesehatan Masyarakat, mengingat jumlah kematian karena Covid19 telah meningkat dan meluas antar wilayah dan berdampak pada kondisi politik, ekonomi, kesejahteraan masyarakat, sosial, budaya, serta pertahanan dan keamanan. Keppres yang ditetapkan ini memperhatikan isi Undangundang Nomor 6 Tahun 2018 tentang kekarantinaan kesehatan. Undang-undang Dasar 1945, Pasal 12 dan Pasal 22, telah memberi dasar jika terjadi keadaan bahaya dan kegentingan yang memaksa. UUD NRI 1945, melindungi segenap warga negara dan tumpah darah Indonesia, dan pemerintah wajib menjamin keselamatan warga negaranya (Presiden Republik Indonesia, "Keputusan Presiden RI Nomor 11 Tahun 2020").

Selain hal tersebut pemerintah juga membatasi ruang gerak warga dalam rangka memutus persebaran virus corona. Pemerintah mengeluarkan kebijakan terkait dengan hal ini melalui Peraturan Pemerintah Nomor 21 Tahun 2020 tentang Pembatasan Sosial Berskala Besar (PSBB) dalam rangka percepatan penanganan Covid-19 dan diturunkan oleh Kementrian Kesehatan melalui peraturan Menteri Kesehatan Nomor 9 Tahun 2020 tentang Pedoman Pembatasan Sosial Berskala Besar Dalam Rangka Percepatan Penanganan Covid-19 (Presiden Republik Indonesia, Peraturan Pemerintah Nomor 21 Tahun 2020 Tentang Pembatasan Sosial Berskala Besar Dalam Rangka Percepatan Penanganan Coronavirus Disease 2019/COVID-19). Dengan keluarnya kebijakan tersebut diharapkan dapat menekan angka kenaikan dari kasus Covid-19, tetapi pada kenyataannya sampai dengan sekarang (22 Juni 2020) angka kasus Covid-19 di Indonesia justru terus bertambah.

Sebagai penyakit yang baru saja muncul, Covid-19 masih berkembang dengan pesat trend-nya. Bagi sebagian orang dengan imunitas yang baik, Covid- 
19 bisa dilawan dengan sistem imun dalam tubuhnya sendiri. Karena orang yang menderita Covid-19 atau terinfeksi virus corona ini bari bisa diketahui setelah melakukan test tertentu. Unttuk membantu pemerintah dan pihak kesehatan menganalisis para pasien, maka ada 4 (empat) sebutan orang terkait Covid-19 yaitu:

1. Orang dalam pemantauan (ODP).

2. Pasien dalam pengawasan (PDP) atau suspek.

3. Orang tanpa gejala (OTG)

4. Posistif Covid-19.

Orang dalam pemantauan (ODP) merupakan orang yang memenuhi sejumlah kriteria : Deman $\left(\right.$ suhu $\geq 38^{\circ} \mathrm{C}$ ) atau riwayat deman, batuk atau pilek, memiliki riwayat perjalanan ke Negara yang memiliki transmisi lokal Covid-19, tinggal didaerah dengan transmisi lokal di Indonesia dalam 14 hari terakhir sebelum timbul gejala, namun tidak memiliki riwayat kontak dengan orang posistif Covid-19 (Abudi et al.).

Virus corona diperkirakan menyebar di antara orang-orang melalui percikan pada saat batuk dan bersin. Penyakit Covid-19 dapat menular dengan adanya gejala dan tanpa gejala. Masa inkubasi terjadi dalam kurun waktu 7 sampai 14 hari (Nakoe et al.).

Keberadaan virus corona memberikan banyak perubahan pada tatanan kehidupan masyarakat dunia. Adanya pandemi ini tentunya akan menjadikan banyak negara

\section{METODE PENELITIAN}

Metode kualitatif digunakan dalam penelitian ini dengan pendekatan kepustakaan. Analisis data yang digunakan adalah deskriptif. Penelitian kualitatif diartikan sebagai proses eksplorasi dan memahami makna dari perilaku individu berada dalam situasi krisis hebat. Untuk mengatasi hal tersebut keputusan pemerintah tentang akan dilakukannya kenormalan baru atau yang disebut dengan new normal sangat tepat. Secara global WHO juga telah memberikan skenario dalam pelaksanaan kenormalan baru di tengah pandemi (Januar Mahardhani).

Dalam perusahaan harus dapat memastikan aktivitas karyawan agar tetap lancar dan aman. Dengan diberlakukannya new normal, karyawan diharapkan dapat kembali menjalankan aktivitas seperti sediakala. Perusahaan kembali beroperasi dengan beberapa penyesuaian, yaitu mengurangi kontak fisik, menghidari kerumunan dan melakukan proteksi diri dengan menggunakan masker saat bepergian, sesuai anjuran pemerintah. Baik perusahaan swasta maupun instansi pemerintah harus mempertimbangkan banyak hal sebelum memutuskan sistem kerja baru lagi (Hartono). Pandemi Covid19 telah secara drastis mengubah keseharian masyarakat di seluruh dunia. Demi mencegah penyebaran dan menghindari dari risiko tertular Covid-19 (Tuti et al.). Pencegahan dapat dilakukan dengan beberapa langkah yang direkomendasikan yaitu memakai masker, mencuci tangan dengan sabun dan menjaga jarak dengan orang lain serta meningkatkan imunitas tubuh dengan mengkonsumsi vitamin sehingga dapat memutus rantai penyebaran Covid-19 (Nakoe et al.).

dan kelompok, serta menggambarkan masalah sosial atau masalah kemanusiaan yang ada di sekitar kita. Sedangkan bersifat deskriptif dikarenakan dalam penelitian ini bertujuan untuk memahami makna dan keunikan obyek yang diteliti 
serta memahami interaksi sosial yang ada antar masyarakat (Sugiyono).

penelitian ini dilaksanakan dari tanggal 31 Agustus - 28 September 2020. Lokasi yang di pilih menjadi tempat penelitian adalah lingkungan PT. IndoKordsa Tbk, J1. Pahlawan, Desa Karang Asem Timur, Citeureup, Bogor, Jawa Barat. Jumlah responden dari penelitian ini 1025 karyawan.

Dari penelitian ini besar sampel di ambil berdasarkan sample minimal, yaitu teknik penentuan sampel dengan mengambil seluruh jumlah responden mejadi sampel. Sampel yang diambil adalah seluruh jumlah responden yang ada sehingga tidak dilakukan pengambilan sampel karena seluruh jumlah responden akan mejadi sasaran penelitian (Suharjo).

Metode penelitian dilakukan dengan cara memasang poster di lingkungan perusahaan, setiap komputer diberikan screen server tentang bahaya penularan virus corona dan himbauan peraturan protokol kesehatan lewat speaker setiap menjelang isrihatat pertama dan kedua. Dengan tujuan setiap individu dapat memahami dan mematuhi protokol kesehatan sesuai peraturan perusahan demi mencegah penularan Covid-19.

Salah satunya dengan cara social distancing, physical distancing dan mematuhi 3M yaitu memakai masker, mencuci tangan dengan sabun atau hand sanitizer dan menjaga jarak. Penerapan dilakukan dengan cara memberi jarak antar pekerja pada saat masuk pabrik untuk dilakukan screening awal seperti pemeriksaan suhu, gejala batuk dan flu.

\section{HASIL DAN PEMBAHASAN}

Proteksi diri adalah upaya melindungi dari penularan penyakit. Beberapa upaya
Pekerja pada saat istirahat makan di kantin diharapkan mencuci tangan telebih dahulu dengan sabun dan menjaga jarak antar pekerja yang sudah di beri tanda pada saat antri makan di kantin, dan pekerja yang ingin melakukan ibadah di masjid diharapkan membawa sajadah, mukena pribadi dan mejaga jarak sesuai tanda yang sudah diberikan.

Flow chart penelitian

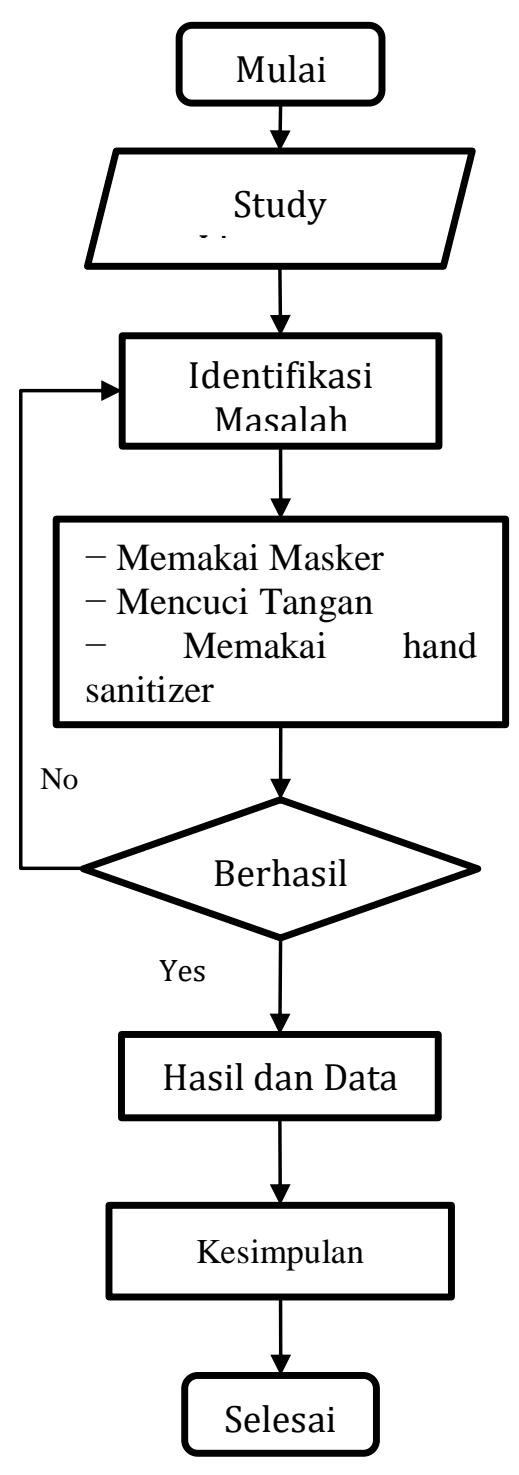

Gambar 2.1 Flow chart penelitian

pencegahan antara lain : 
1. Pencegahan virus corona pada transportasi umum. Selama pandemi Covid-19 pada saat mengunakan fasilitas transportasi umum harus selalu menggunakan masker, faceshield, dan wajib untuk menjaga jarak antar penumpang yaitu satu meter. Selain itu juga diusahakan untuk tidak memegang gagang pintu serta pegangan yang ada di dalam kendaraan. Usahakan juga untuk selalu membawa hand sanitizer dan menggunakan sarung tangan jika memang dibutuhkan.1

2. Mencegah virus selama beraktivitas di tempat kerja. Pada saat telah sampai di tempat kerja maka yang pertama wajib dilakukan adalah mencuci tangan dengan air yang mengalir dan sabun, setelah itu wajib ada pemeriksaan suhu tubuh menggunakan termometer. Diwajibkan juga untuk menjaga jarak minimal satu meter pada saat absen masuk. Hal-hal yang perlu diperhatikan saat mencuci tangan antara lain : Bila terlihat jelas terkontaminasi oleh bahan yang mengandung protein, tangan harus dicuci dengan memakai sabun dan air yang mengalir. Bila tangan tidak terlihat kotor atau terkontaminasi, harus menggunakan antiseptik berbasis alkohol untuk detokminasi tangan rutin. Sebelum memulai kegiatan tangan dipastikan dalam keadaan kering.

Membersihkan tangan dengan air dan sabun tingkat keampuhan menghilangkan bakteri ditangan dapat berbeda, dalam hal ini jika hanya mencuci dengan air, bakteri yang akan keluar hanya sedikit, sedangkan apabila menggunakan sabun dapat membunuh bakteri karena dalam sabun terdapat bahan khusus yang dapat mengendalikan yang ada pada tangan, dalam hal ini terdapat beberapa bahan aktif yang terkandung dalam sabun cuci tangan yaitu alkohol, emollient, triclocarban, triclosan dan lainnya.

Hand-sanitizer yaitu sebuah produk berbentuk gel yang memiliki kandungan antiseptik sebagai perbersih tangan yang jika menggunakannya tidak perlu dibilas dengan air. Menggunakan hand-sanitizer sangat efektif mematikan flora transien dan residen dibandingkan dengan menggunakan air, pakai sabun biasa maupun sabun antiseptik. Berdasarkan food and drug administration (FDA) bahwa hand-sanitizer dapat membunuh kuman kurang waktu 30 detik.

Kandungan hand-sanitzer memiliki berbagai macam zat yang terkandung. Secara umum mengandung alkohol 6090\%, benzalikonium chloride, benzethonium chloride, chlorhexidine, gluconatee, chloroxylenolf, clofucarbang, hexachlorophene, hexylresocarcinol, iodine and iodophors, dan triclosan. Tetapi yang sering digunakan dalam masyarakat atau yang sering dipakai oleh banyak orang adalah yang kandungannya alkohol dan triclosan. Pada produk hand-sanitizer terdapat beberapa campuran emolien bermanfaat sebagai pelindung dan pelembut kulit. Hand-sanitizer ini juga bisa menjaga dan menghaluskan kulit karena terdapat emolien seperti gliserin, glisol propelin, atau sorbitol. Menurut Center for Disease Control (CDC) hand-sanitizer terbagi menjadi dua yaitu mengandung alkohol dan tidak mengandung alkohol. Hand-sanitizer dengan kandungan alkohol antara 60-90\% memiliki efek anti mikroba yang baik dibandingkan tanpa kandungan alkohol. Hand-sanitizer tidak mengilangkan kotoran atau zat organik, sehingga jika tangan sangat kotor atau terkontaminasi oleh darah atau cairan tubuh, harus dicuci terlebih dahulu dengan air menggunakan sabun. selain itu juga 
bisa berkurangnya emolien yang menumpuk ditangan setelah berulang kali memakai hand-sanitizer, walaupun sudah memakai hand-sanitizer tetapi dianjurkan untuk tetapa mencuci tangan dengan sabun, selesai memakai hand-sanitizer 510 kali. Bahan aktifnya hanya alkohol mempunyai pengaruh residual terbatas dibandingkan dengan hand-sanitizer yang berisi campuran alkohol antiseptik seperti chlorhexidine.

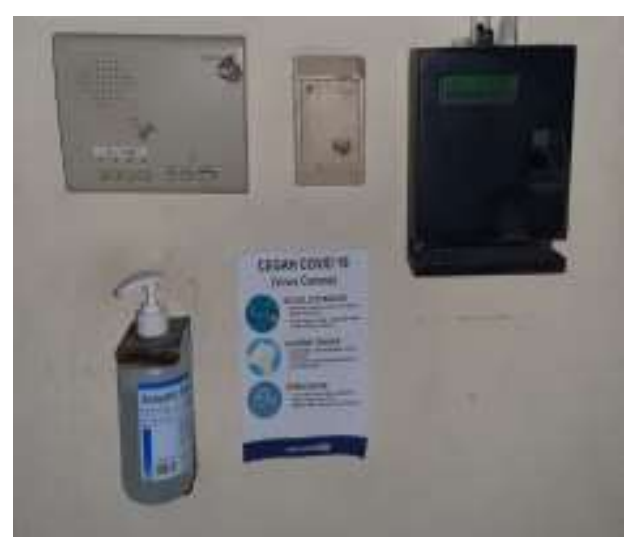

Gambar 3.1 Tempat absen In Out

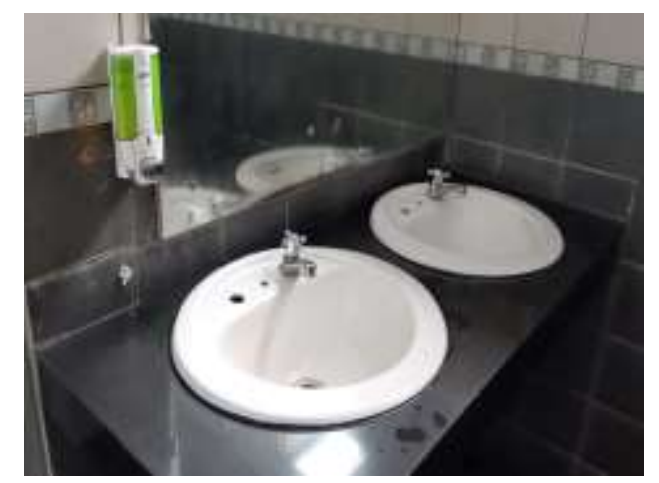

Gambar 3.2 Tempat mencuci tangan dengan sabun

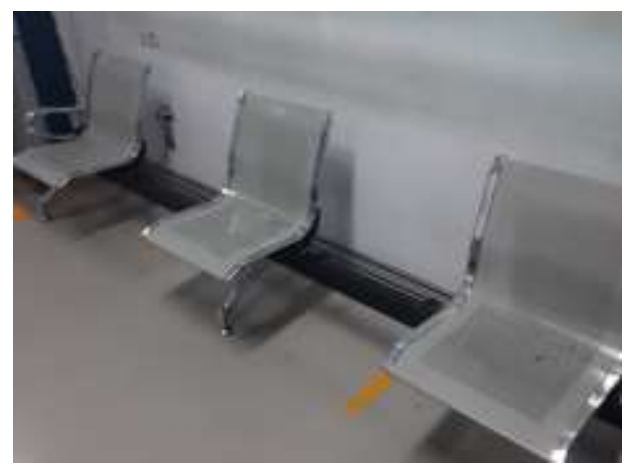

Gambar 3.3 Tempat duduk (Menjaga jarak)
Dalam melakukan interkasi dengan teman di tempat kerja. Selama beraktivitas di tempat kerja harus menerapkan perilaku new normal untuk pencegahan virus, di antaranya menggunakan masker dan faceshield, menggunakan hand sanitizer setelah bersentuhan atau memagang benda di tempat kerja yang berpotensi dipegang oleh banyak orang, sering mencuci tangan, menjaga kebersihan benda di sekitar tempat aktivitas bekerja, menutup hidung dan mulut menggunakan tisu ketika bersin, atau batuk, dan tidak membuang tisu bekas sembarangan. Jika kondisi tubuh tidak memungkinkan untuk beraktivitas di tempat kerja maka diwajibkan untuk melakukan aktivitas kerja dengan bekerja dari rumah atau work from home (WFH).

3. Selalu menjaga kebersihan lingkungan tempat kerja. Perusahaan harus memastikan bahwa seluruh area yang digunakan untuk beraktivitas tetap bersih dan higienis dengan melakukan pembersihan secara berkala menggunakan desinfektan. Area yang wajib selalu untuk dibersihkan secara berkala setiap hari adalah pegangan pintu dan tangga, peralatan kantor, dan fasilitas umum lainya. Selain itu juga harus selalu menjaga kualitas udara di lingkungan tempat kerja dengan cara mengoptimalkan sirkulasi udara, mengatur sinar matahari yang masuk ruangan kerja, dan pembersihan filter air conditioner (AC).

4. Setelah berpergian sampai di rumah lakukan pencegahan dengan membersihkan diri sebelum bertemu anggota keluarga di rumah. Aktivitas yang dilakukan adalah membuka sepatu atau sandal dan menjemurnya ditempat yang terkena sinar matahari langsung atau dapat juga dengan menyemprot sepatu atau barang yang 
telah dipergunakan selama beraktivitas di luar seperti tas, pakaian, ponsel, laptop dan pulpen menggunakan cairan disinfektan. Sebelum melakukan aktivitas lainnya dirumah maka dianjurkan untuk mandi agar virus yang menempel di bagian tubuh luar dapat langsung mati.

5. Selalu menjaga daya tahan tubuh selama menjalani new normal. Menjaga kekebalan tubuh sangat penting untuk dilakukan agar tetap sehat dan terhindar dari penyakit. Berbagai cara untuk menjaga daya tahan tubuh agar kuat adalah dengan minum air putih yang cukup (delapan gelas sehari), makan makanan yang bergizi, rutin untuk melaksanakan olahraga, durasi tidur yang cukup, minum vitamin, dan selalu mencuci tangan setelah melakukan aktivitas.

6. Tidak sembarangan mengkonsumsi makanan dan obat-obatan. Sebelum membeli dan mengonsumsi obat dan produk makanan yang akan di beli harus melihat kemasan dengan seksama, memeriksa label, izin edar, dan tanggal kadaluwarsa yang tertulis di wadah obat atau makanan dan selalu melihat adanya rekomendasi dari Badan Pengawas Obat dan Makanan (BPOM).

Pekerja pada saat menjelang istirahat pertama dan kedua selalu di imbau dengan adanya pemberitahuan menggunakan mikrofon agar karyawan selalu menaati peraturan yang sudah di berlakukan. Seperti tidak diperbolehkan makan di luar, mencuci tangan terlebih dahulu dangan sabun sebelum makan dan menjaga jarak antar pekerja yang sudah di beri tanda pada saat antri makan di kantin. Dengan peraturan yang sudah ada dan di awasi oleh security semua kayawan bisa memaklumi pada saat menjelang makan terjadi antrian yang panjang yang menyebabkan waktu jam makan terbuang. Demi menjalankan protokol kesehatan seperti menjaga jarak dan kerumunan untuk kepentingan bersama, supaya meminimalisir tertular dari Covid-19. Pekerja yang ingin melakukan ibadah di masjid wajid menggunakan masker, membawa sajadah, mukena pribadi dan mejaga jarak sesuai tanda yang sudah diberikan.

Data jumlah pelangaran yang dilakukan karyawan dapat dilihat tabel berikut.

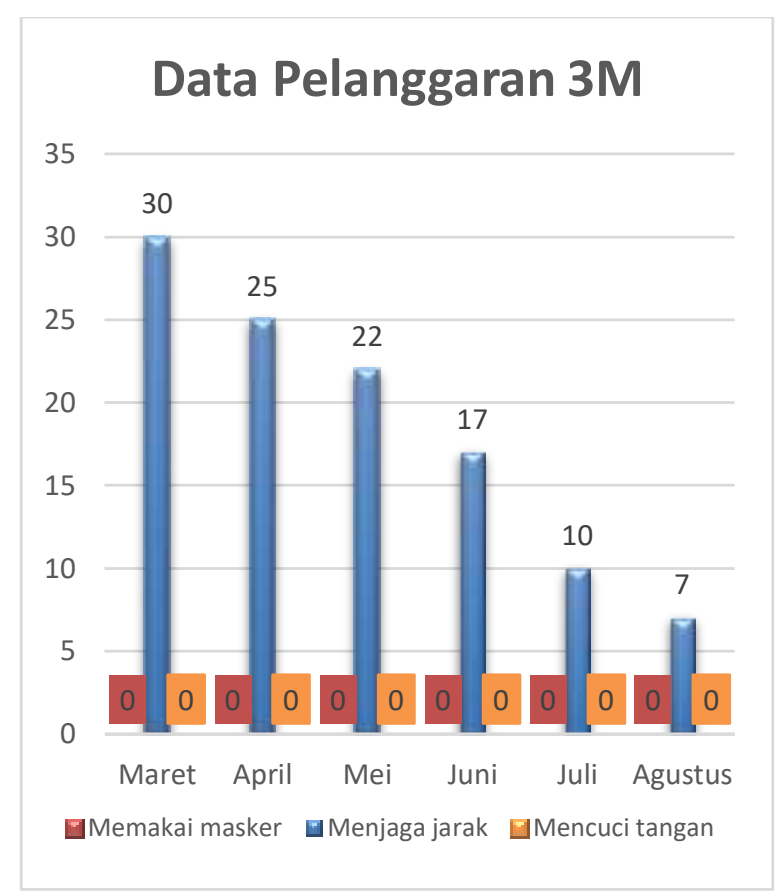

Gambar tabel 3.4 Pelanggaran 3M

Pelanggaran yang sering di lakukan adalah menjaga jarak pada saat absen masuk, pulang dan menjelang waktu makan di shift sore dan malam. Banyak karyawan yang mengabaikan karena tidak ada yang mengawasi pada waktu shift sore dan malam. Kedisiplinan sangat penting sebagai kunci utama dalam menghadapi pandemi Covid-19. Berdisiplin akan menjadi penangkal virus yang sangat penting dan secara otomatis akan 
menjadikan virus Covid-19 ini segera hilang dan masyarakat bebas dalam melakukan segala aktivitas. Tentunya selain hal tersebut masyarakat atau karyawan swasta juga wajib untuk mengikuti kebijakan yang dikeluarkan oleh pemerintah seperti mematuhi protokol kesehatan di setiap adanya kegiatan dan berkunjung ke tempat lain. Dengan melaksanakan hal tersebut maka kenormalan baru akan dapat berakibat positif.

\section{KESIMPULAN}

Berdasarkan dari hasil penelitian analisis dan pembahasan yang sudah di jabarkan pada bab sebelumnya dapat di tarik kesimpulan pada proteksi diri saat pandemi Covid-19 di lingkungan perusahaan pada tahun 2020.

Pandemi Covid-19 mengubah kehidupan sehari-hari serta di lingkungan perusahaan. Kedisiplinan sangat penting sebagai kunci utama dalam mencegah

\section{UCAPAN TERIMA KASIH}

Alhamdulillah, Puji dan syukur saya panjatkan kehadirat Allah SWT yang telah memberikan rahmatnya serta hidayah-Nya saya dapat menyelasaikan laporan ini. Saya ucapkan terimakasih kepada semua pihak
Dengan adanya fasilitas yang sudah di berikan seperti handsanitizer, masker, vitamin dan melaksankan protokol kesehatan secara ketat terhadap 1200 karyawan, 100 persen sehat dari bulan Maret sampai dengan pertengahan September. Karyawan dapat bekerja dengan nyaman dan produksi dapat berjalan dengan lancar. Dengan kesadaran pentingnya proteksi diri dari pandemi Covid-19.

penularan Covid-19. Perusahaan mematuhi protokol kesehatan seperti memakai masker, cuci tangan atau memakai handsanitizer, menjaga jarak antar pekerja. Pandemi Covid-19 telah memberikan dampak perilaku baru pada karyawan, yaitu jauh lebih peduli terhadap kebersihan, kesehatan dan keselamatan di lingkungan perusahaan.

yang telah membantu dalam proses pembuatan laporan ini dengan tepat waktu, dan tidak lupa management yang telah memberi dukungannya dalam proses pembuatan jurnal ini. 


\section{DAFTAR PUSTAKA}

Abudi, Ramly, et al. "Stigma Terhadap Orang Positif Covid-19." Jambura Journal of Health Sciences and Research, vol. 2, no. 2, 2020, pp. 7784, doi:10.35971/jjhsr.v2i2.6012.

Hartono. Talent Management Perusahaan Multinasional Menuju Era New Normal Tantangan Dan Peluang. no. 1, 2020, p. 55.

Januar Mahardhani, Ardhana. "Menjadi Warga Negara Yang Baik Pada Masa Pandemi Covid-19: Persprektif Kenormalan Baru." Jurnal Pancasila Dan Kewarganegaraan, vol. 5, no. 2, 2020, pp. 65-76, doi:10.24269/jpk.v5.n2.2020.pp6576.

Nakoe, Rivai, et al. "Perbedaan Efektivitas Hand-Sanitizer Dengan Cuci Tangan Menggunakan Sabun Sebagai Bentuk Pencegahan Covid-19." Jambura Journal of Health Sciences and
Research, vol. 2, no. 2, 2020, pp. 6570, doi:10.35971/jjhsr.v2i2.6563.

Presiden Republik Indonesia. "Keputusan Presiden RI Nomor 11 Tahun 2020." Penetapan Kedaruratan Kesehatan Masyarakat, no. 031003, 2020.

Peraturan Pemerintah Nomor 21 Tahun 2020 Tentang Pembatasan Sosial Berskala Besar Dalam Rangka Percepatan Penanganan Coronavirus Disease 2019/COVID-19. no. 022868, 2020, p. 8.

Sugiyono. Metode Penelitian Kualitatif. 2018.

Suharjo. Managemen Teori Praktik Dan Riset Pendidikan. 2008.

Tuti, M., et al. Pentingnya Protokol Kesehatan Keluar Masuk Rumah Saat Pandemic Covid-19. 